\title{
Modeling of Spacio-temporal Evolution of Salt Dispersion on Nokoue Lake
}

\author{
Esdras Babadjidé Josué Zandagba ${ }^{1,2}$, Eric Adéchina Alamou ${ }^{1,2}$, Ezechiel Obada ${ }^{1,2}$, Amédée Chabi ${ }^{1}$, \\ Eliézer Iboukoun Biao ${ }^{1,2}$, and Abel Afouda ${ }^{1}$ \\ ${ }^{1}$ Laboratory of Applied Hydrology, National Water Institute, University of Abomey-Calavi, \\ Abomey Calavi, Benin \\ ${ }^{2}$ Laboratory of Geosciences, Environment and Applications, National University of Sciences, Technology, \\ Engineering and Mathematics, Abomey, Benin
}

Correspondence: Esdras Babadjidé Josué Zandagba (zjosuas@ gmail.com)

Published: 16 November 2021

\begin{abstract}
The numerical modeling of spatio-temporal evolution of lagoon has an important role in predicting the behaviour of these systems. Knowing the concentration of the pollutant field distribution in time and space contributes significantly to the prediction of exceptional phenomena. The purpose of this paper is to simulate the transport and dispersion of salt at Nokoue Lake. To this end, the 2D hydrodynamic model SMS (Surface Water Modeling System) has been used. Results showed that in flood period the freshwater inflows produce a net seaward transport, while in low water period the tides lead to periodic seaward and landward transport. The developed numerical model is useful for predicting pollutants transport in this system, for water quality management of the Nokoue Lake, and therefore, fight against eutrophication.
\end{abstract}

\section{Introduction}

Ecological processes in coastal and estuarine areas strongly depend on dynamic physical processes, such as water surface inundation, residence time, circulation and salinity variation (Zhaoqing et al., 2010).

Estuaries are highly variable in physical, chemical, and biological properties. Tides and freshwater inflows are the two major external forcing mechanisms controlling estuarine processes. The interest and driving force in studying the ecology of the lagoon comes from increasing threats to the lagoon by siltation, choking of the mouth connecting the lagoon to the sea, eutrophication weed infestations, salinity changes and a decrease in fishery resources (Jayaraman et al., 2007). Due to their location at the junction of terrestrial, aquatic and marine ecosystems, lagoons constitute particularly important transitional ecosystems, whose hydrological and ecological functions are a source of ecosystem services (Tunin-Ley et al., 2014).

Faced to this, modern and efficient management of the water resources of these ecosystems is essential. This requires a detailed description of the various processes that take place, which necessarily involves in observation and modeling. $\mathrm{Nu}-$ merical modeling has been demonstrated as a useful and efficient tool to predict ecological change under varying physical processes and hydrological conditions and to provide guidance for estuarine and coastal restoration projects (Boumans et al., 2002; Roman et al., 1995; Silvestri et al., 2005; Yang et al., 2008).

Characterized by continental and marine interactions, various pollutions and the development of aquatic plants, Nokoue Lake has become the site of complex phenomena, which should be studied and mastered, in a context of climate change. Thus Zandagba et al. (2016) study the hydrodynamic functioning of Nokoue Lake and show that the dynamic of the lake is controlled by the tributaries flows in a flood period and by tide during a low water period. It is also characterized by the dephasing and the flattening of the tidal amplitude, which increase as we move away from the channel. In a flood period, contrary to the low-water period, incoming flows are higher than outflows, reinforced by the tidal amplitude. Adandedji et al. (2017) showed that winds, flow and 


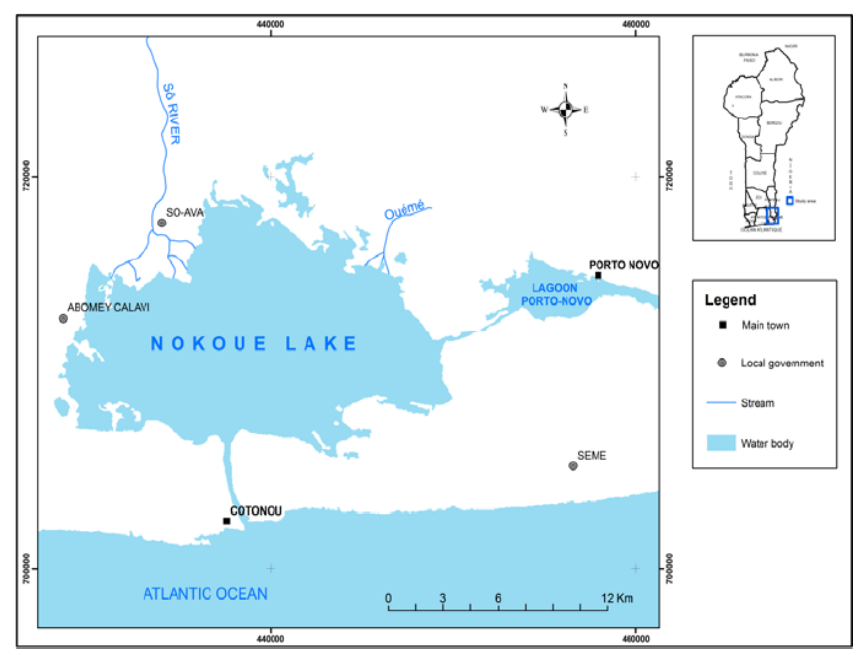

Figure 1. Location of Nokoue Lake (Benin). Source: Topographic bostom (IGN, 1992).

tides are key factors that governs the pathways and pollutants spreading in Nokoue Lake.

Pollutants dispersion processes are often encountered when a quantity of polluted water is discharged into the natural environment, through a controlled or uncontrolled regime. By introducing a pollutant in an aquatic environment, its polyphone constituents are dispersed through the whole volume of water. The mathematical modeling of spatio-temporal evolution of lagoon has an important role in predicting the behaviour of these systems. Knowing the concentration of the pollutant field distribution in time and space contributes significantly to the prediction of exceptional phenomena (Galina et al., 2015).

The purpose of this paper is to simulate the transport and dispersion of salt at Nokoue Lake.

\section{Study area}

Nokoue Lake is located in southern Benin, in West Africa, between $6^{\circ} 25^{\prime} \mathrm{N}$ and $2^{\circ} 36^{\prime} \mathrm{E}$ (Fig. 1). It is located in the sub-equatorial area, and underwent two rainy seasons and two dry seasons of unequal durations. The annual rainfall is $1309 \mathrm{~mm}$, the average temperature of $27.7^{\circ} \mathrm{C}$ with the maxima up to $33^{\circ} \mathrm{C}$ and minimum at $23^{\circ} \mathrm{C}$. It covers an area of $150 \mathrm{~km}^{2}$ and is the largest lake of the country. This lake is connected to Porto-Novo lagoon at the East by the Totche Canal, at south by the Atlantic Ocean through the channel of Cotonou, and at north by the Sô River and the Oueme River on which it depends (Mama, 2010). This communication, together with the impact of natural flood of Sô and Ouémé streams, causes very significant seasonal variations of salinity (Mama, 2010).

\section{Methodology}

\subsection{Modeling}

The numerical model used in this study is the Surface Water Modeling System (SMS) program, which is a software package for efficient management of the process of modeling surface water, temperature, salinity, sediment, and water quality constituents (SMS, 2009).

The hydrodynamic model is driven by tide, river flow, bathymetry and wind stress. It has been calibrated and validated by Zandagba et al. (2016). The development of salinity dispersion was conducted using the SMS Resource Management Associates module 4 (RMA4). To run RMA4, the hydrodynamic solution (velocity and water level simulations) obtained on the lake (Zandagba et al., 2016) were used as input to determine the field evolution of salinity concentrations. In fact RMA4 uses the flow solutions to compute the constituent concentration as it flows through the mesh (RMA4, 2011). The quality module (RMA4) is coupled to the hydrodynamic module, through the transport equation. It integrates the advection and the diffusion properties of the flow, as well as the basic processes occurring in the water column resulting from the interaction between the currents and at the surface and bottom interfaces as well as the major biochemical interactions (Panda et al., 2015).

$$
\begin{gathered}
\frac{\partial h C}{\partial t}+\frac{\partial h C u}{\partial x}+\frac{\partial h C v}{\partial y}=\frac{\partial}{\partial x}\left[h D \frac{\partial C}{\partial x}\right] \\
+\frac{\partial}{\partial y}\left[h D \frac{\partial C}{\partial y}\right]-K h C
\end{gathered}
$$

where $h$ : water depth $(\mathrm{m}), C$ : concentration of pollutant $(\mathrm{mg} / \mathrm{L}), t$ : time (s), $u$ : velocity in the $x$ direction $(\mathrm{m} / \mathrm{s}), v$ : velocity in $y$ direction $(\mathrm{m} / \mathrm{s})$, and $D$ : coefficients of turbulent diffusion in the $x$ and $y, K$ : decay constant $\left(\mathrm{s}^{-1}\right)$ (RMA4, 2011).

Because the water particles velocity depends on the flow and water level, the following boundary conditions were established. In low water period, the constant flowrate of $41 \mathrm{~m}^{3} / \mathrm{s}$ was assigned to Sô river and $14 \mathrm{~m}^{3} / \mathrm{s}$ to Oueme river. In flood period a constant flowrate of 135 and $271 \mathrm{~m}^{3} / \mathrm{s}$ were respectively assigned to Sô and Oueme rivers. Bathymetric and flow data used was obtained from the General Direction of Water at 2017.

At the downstream, hourly tide level with average amplitude was affected.

A constant source of salinity of $12 \%$ during high water periods and $28 \%$ during low water periods in the Cotonou channel were considered.

During high and low water periods, the initial salinity throughout the lake is assumed to be respectively $20 \%$ and $9 \%$. The salinity is considered to be zero for the inflows of the rivers freshwater. The salinity data have been collected at Nokoue lake and cotonou channel, on October and February 2020 , respectively for high and low water period. 


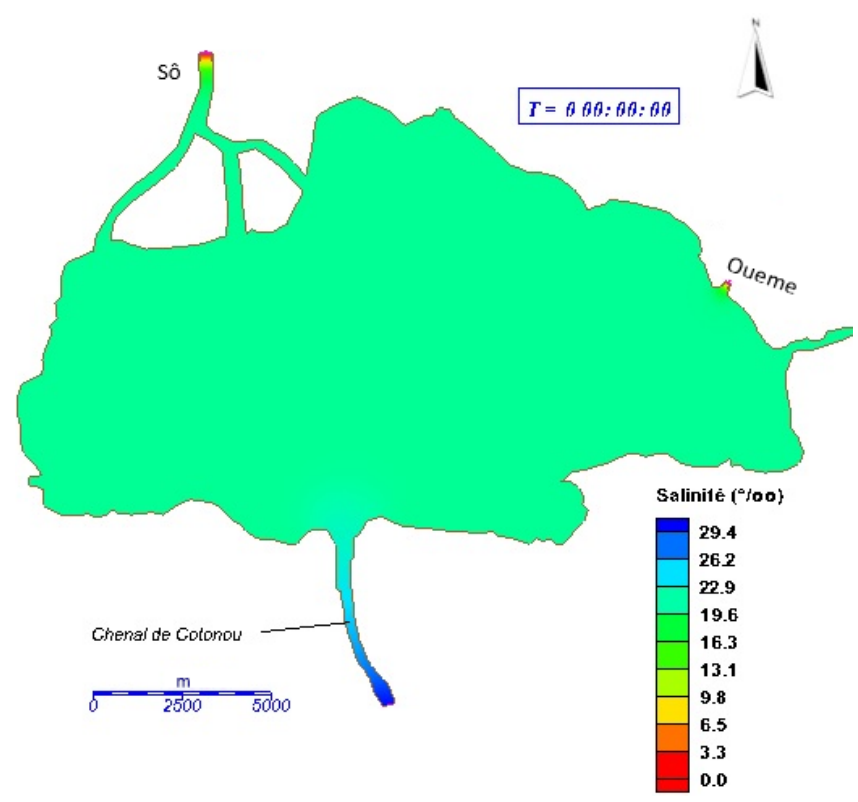

Figure 2. Spatio-temporal variation of salinity-fresh water during the low-flow period at the start of the simulation.

To determine the turbulent diffusion coefficients, two methods are used: direct in which each element receives the respective values of these coefficients, or automatically using the Peclet number which is given by:

$P_{e}=\frac{U \mathrm{~d} x}{D}$

where $U$ : the mean velocity, $\mathrm{d} x$ : element length in the direction of flow, $D$ : turbulent diffusion coefficient (SMS, 2009). The dispersion coefficient $(D)$ is the calibration factor in salinity simulation. Scenarios were simulated with different values of $D$ and optimized with value $1.1 \mathrm{~m}^{2} / \mathrm{s}$.

\section{Results and discussion}

\subsection{Simulation of the dispersion of salinity during low water period}

Figures 2 to 5 show the spatio-temporal evolution of salinity during the low-flow period. The Figs. 2 and 3 respectively show the spatial evolution of salinity at the start of the simulation and after $4 \mathrm{~h}$ of simulation.

The analysis of Fig. 3 indicates that after $4 \mathrm{~h}$ of simulation, the salt water of Ocean Atlantic migrated from Cotonou channel to entrance of the lake.

After $4 \mathrm{~d} 18 \mathrm{~h}$ of simulation (Fig. 4), the plume (salt waterfreshwater) was observed beyond the center of the lake, about $7 \mathrm{~km}$ from the entrance of the channel into the lake and covers about $1 / 3$ of the Lake.

From the 8th day of simulation (Fig. 5), salt water occupies the entire lake and we can also notice that marine waters goes up towards the rivers.

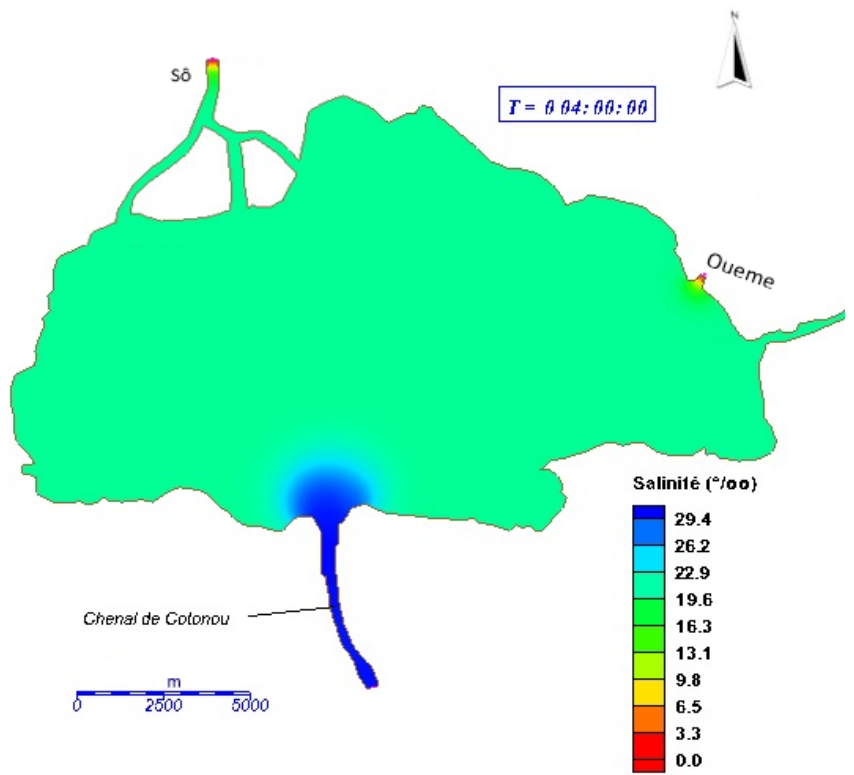

Figure 3. Spatio-temporal variation of salinity-fresh water during the low-flow period after $4 \mathrm{~h}$ of simulation.

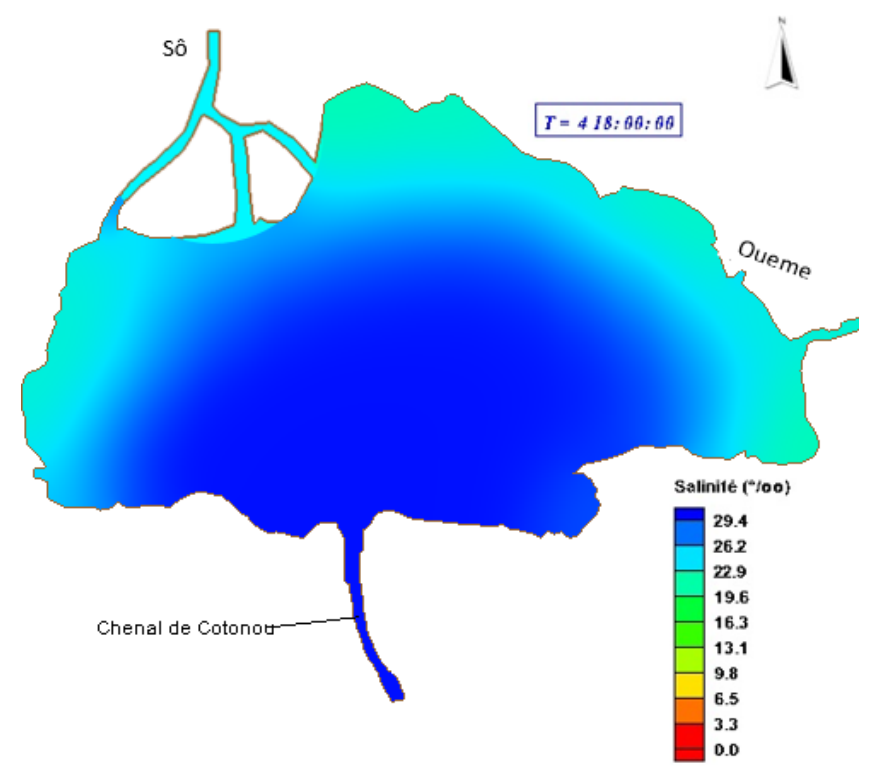

Figure 4. Spatio-temporal variation in salinity - fresh water during the low water period after $4 \mathrm{~d} 18 \mathrm{~h}$.

\subsection{Simulation of the dispersion of salinity during flood period}

Figures 6, 7 and 8 show the spatio-temporal evolution of salinity during a flood period in the lake. 


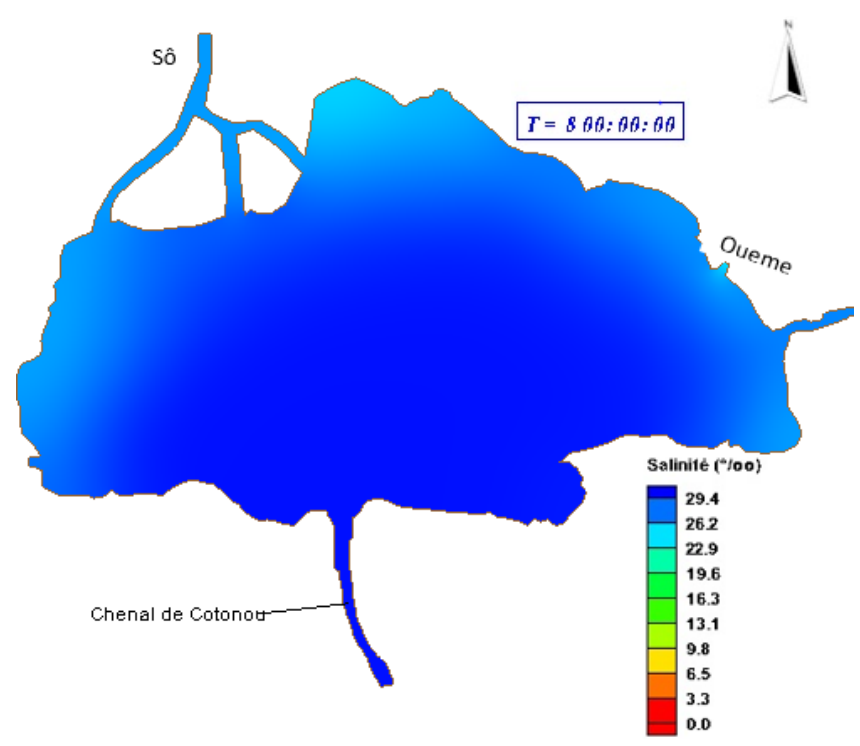

Figure 5. Spatio-temporal variation in salinity - fresh water during the low water period after $8 \mathrm{~d}$ of simulation.

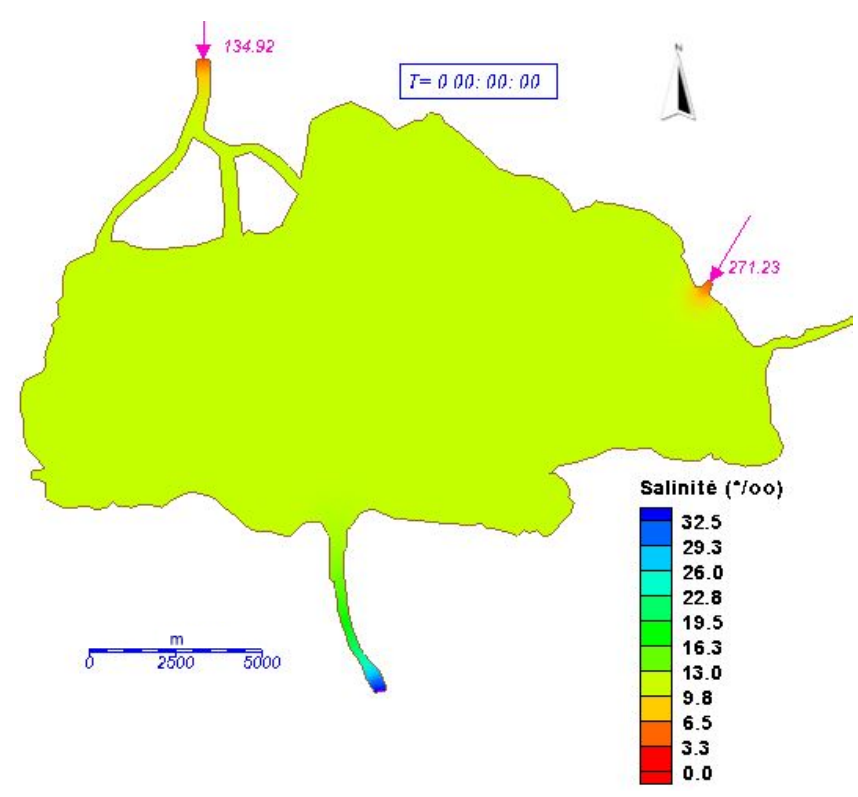

Figure 6. Spatio-temporal variation in salinity during a flood period at the start of the simulation.

Figures 6 and 7 respectively show the spatial evolution of salinity at the start of the simulation and after $8 \mathrm{~h}$ of simulation.

Their analysis indicate that from the start of the simulation, seawater rises through the channel to reach the entrance of the lake after $8 \mathrm{~h}$ simulation.

The Fig. 8 shows that from the 5th day of simulation the dispersion of salt water was completely stopped. Indeed, the three-quarters of the lake are controlled by the fresh water

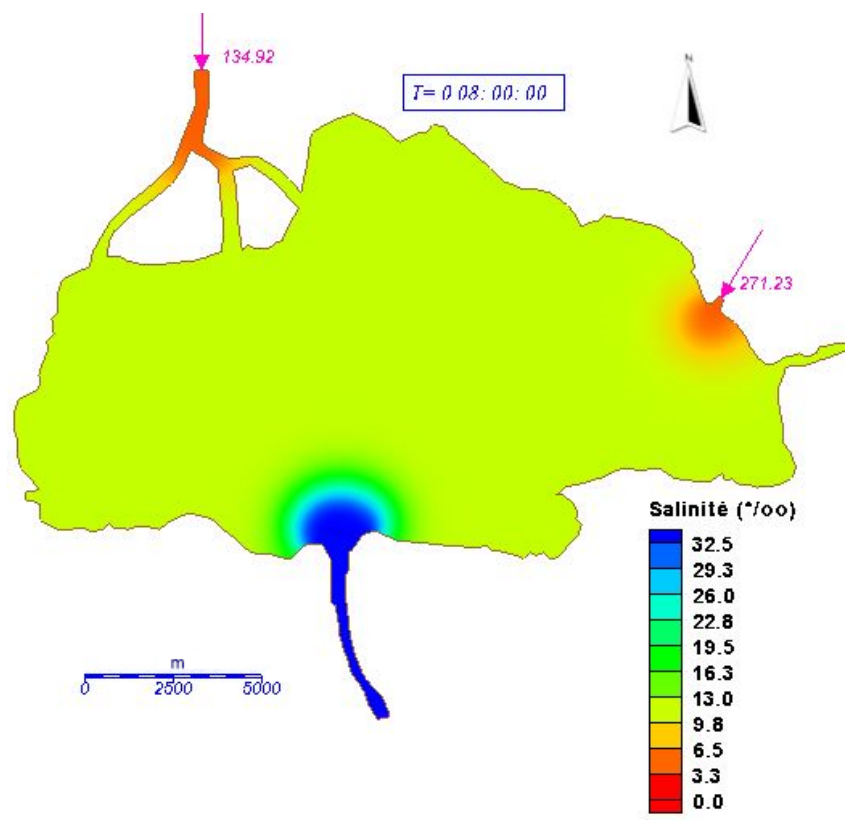

Figure 7. Spatio-temporal variation in salinity during a flood period after $8 \mathrm{~h}$ of simulation.

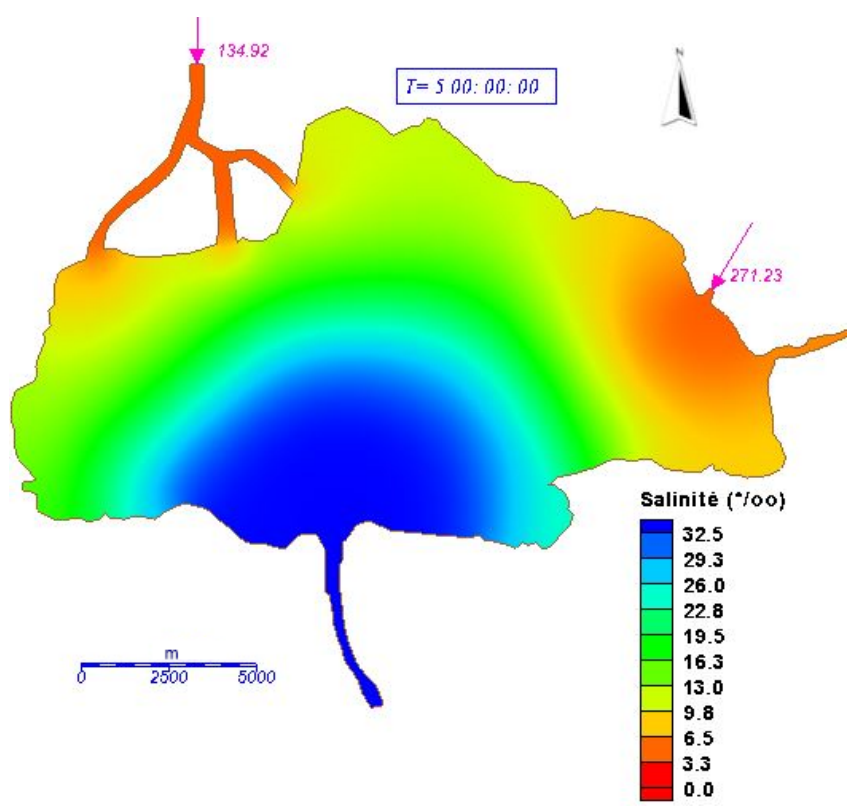

Figure 8. Spatio-temporal variation in salinity during a flood period after $5 \mathrm{~d}$ of simulation.

brought by the rivers whose quantity prevents the migration of salt water towards the bottom of the lake.

\subsection{Discussion}

Analysis of the dispersion and transport of salt reveals a clear increase in salinity from the ocean to the lake during low- 
flow periods. This evolution up rivers and was felt up to Bonou according to Mama (2010).

At the end of the simulation, we note that the migration of fresh water from Oueme and Sô rivers is limited to entering the lake during low-water periods, while in high-water periods it is limited to entering the lake reached 3 to $5 \mathrm{~km}$ in the lake. In fact, the large freshwater discharge makes it difficult for seawater to be transported into the lake from the open ocean. This is in accordance with the results of Jayaraman et al. (2007) according to which in this period the persistent large freshwater inflows flush the salt out to the ocean.

The contact zone between the salt water and the fresh water inflows characterized by a plume is located a little before the center of the lake during the flood period, while in the low water period it is close to the entrances of Oueme and Sô rivers. The intrusion of marine waters into the lake is therefore greater during low flow than during high water, which was in accordance with the results of Zandagba et al. (2016), according to whom the dynamic of the lake is controlled by the tide in period of low water. The freshwater inflows produce a net seaward transport, while the tides lead to periodic seaward and landward transport. The freshwater tends to float over the denser seawater, but tidal mixing reduces this stratification.

According to Dehotin et al. (2007), this behavior is common to all tropical ecosystems characterized by desalination in the flood period and high salinity in the dry season. The simulation confirmed the general pattern of salinity intrusion through inlet, low salinity of northern sector, medium salinity of central and southern sector (Panda et al., 2015; Adandedji et al., 2017).

The results also revealed that the temporal variability of the system is mainly due to the disparity of the seasonal changes in salinity like found by Wango (2019). The spatial variation in the salinity reveals the importance of tributary discharges.

Due to an array of physical processes taking place together, Nokoue Lake environment becomes more dynamic and there exists a greater degree of salinity variations. Lower salinity values in the northern sector could be related to severe dilution as a consequence of addition of massive freshwater into this sector by rivers.

\section{Conclusions}

The 2D hydrodynamic model SMS has been used to investigated the transport and dispersion of the salt on Nokoue Lake. To this end, the RMA4 program allowed to determine the evolution of salt dispersion in time and space on the studied area. The obtained results showed that freshwater inflow plays a major role in flood period while it is the tide that controls the dynamics during low water periods. It was also found that in low water period from 8th day of simulation, salt water occupies almost the entire lake. However in flood period, from the 4th day, the dispersion of salt water begins to be slowed down and the transport has become stationary from the 5th day. It is concluded that the entrance is a critical element affecting the exchange of water between the sea and lagoon.

The developed numerical model is useful for predicting pollutants transport in this system, for water quality management of the Nokoue Lake, and therefore, fight against eutrophication.

Data availability. All data used in this manuscript are available upon request from the corresponding author.

Author contributions. EBJZ, EAA, EO, AC, EIB and AA designed the study, developed the methodology and wrote the manuscript; EBJZ performed the field work, collected the data and conducted the computer analysis.

Competing interests. The contact author has declared that neither they nor their co-authors have any competing interests.

Disclaimer. Publisher's note: Copernicus Publications remains neutral with regard to jurisdictional claims in published maps and institutional affiliations.

Special issue statement. This article is part of the special issue "Hydrology of Large River Basins of Africa". It is a result of the 4th International Conference on the "Hydrology of the Great Rivers of Africa", Cotonou, Benin, 13-20 November 2021.

Acknowledgements. Thank to the International Foundation for Science (IFS) for supporting this work.

Financial support. This research has been supported by the International Foundation for Science (grant no. 1I2_W_5706).

\section{References}

Adandedji, F. M., Sintondji, L. O., Mama, D., and Vested, H. J.: Pollutants dispersion in tropical coastal lake based on numerical modeling approach: A case study of Nokoué Lake in the Republic of Benin, Int. J. Sci. Eng. Res., 8, 1369-1374, 2017.

Boumans, R. M. J., Burdick, D. M., and Dionne, M.: Modeling habitat change in salt marshes after tidal restoration, Restor. Ecol., 10, 543-555, 2002.

Dehotin, U. A., Laleye, P. A., Dauta, A., and Moreau, J.: Facteurs ecologiques et diversité piscicole d'une lagune Ouest Africaine: Le lac Nokoué au Bénin, Journal of Afrotropical Zoology, 49-55, 2007. 
Galina, M., Ion, S., Violeta, V., Constantin, F., Nina, S., and Monica, A. C.: Modeling of Spacio-temporal Evolution of Fluoride Dispersion in "River-type" Systems, Rev. Chim. (Bucharest), 66, 503-506, 2015.

Institut Géographique National (IGN): Annal des données topographiques du Bénin, Vol. 2, 32 pp., 2007.

Jayaraman, G., Rao, A. D., Dube, A., and Mohanty P. K.: Numerical simulation of circulation and salinity structure in Chilika Lagoon, J. Coast. Res., 23, 861-877, 2007.

Mama, D.: Méthodologie et résultats du diagnostic de l'eutrophisation du lac Nokoué (Bénin), Mémoire de Thèse de l'Université de Lausanne, Lausanne, 157 pp., 2010.

Panda, U. S., Mahanty, M. M., Ranga Rao, V., Patra S., and Mishra, P.: Hydrodynamics and water quality in Chilika Lagoon - A modelling approach, 8th International Conference on Asian and Pacific Coasts (APAC 2015), Proc. Eng., 116, 639-646, 2015.

Roman, C. T., Garvine, R. W., and Portnoy, J. W.: Hydrologic modeling as a predictive basis for ecological restoration of salt marshes, Environ. Manag., 19, 559-566, 1995.

Silvestri, S., Defina, A., and Marani, M.: Tidal regime, salinity and salt marsh plant zonation, Estuar. Coast. Shelf Sci., 62, 119-130, 2005.

Surface Water Modeling System (RMA4): US Army Engineer Research and Development Center, 2011.
Surface Water Modelling System (SMS): Users Guide to RMA2, US Army Corps of Engineer-Waterways Experiment Station: Vicksburg, MS, USA, 296 pp., 2009.

Tunin-Ley, A., Malet, N., Fiandrino, A., Orsoni, V., and Baldi, Y.: Estimation des échanges entre la mer et la lagune de Biguglia: Utilisation de la méthode d'estimation des volumes d'eau échangés entre la mer et les lagunes par différence de hauteurs d'eau, IFREMER, 29 p., 2014.

Wango, T. E.: Modélisation de l'hydrodynamique, de la dispersion du sel et de l'eau douce dans le complexe lagunaire de la Côte d'Ivoire (Grand-Lahou, Ebrié et Aby), Thèse de Doctorat en Géologie Marine (océanologie), Université de Cocody, 188 pp., 2009.

Yang, Z., Khangaonkar, T., Calvi, M., and Nelson, K.: Evaluation of nonlinear cumulative effect of estuarine restoration projects using a three-dimensional hydrodynamic model, Ecol. Modell. 221, 969-977, https://doi.org/10.1016/j.ecolmodel.2008.12.006, 2008.

Zandagba, J., Moussa, M., Obada, E., and Abel Afouda: Hydrodynamic Modeling of Nokoué Lake in Benin, 2016, Hydrology, 3, 44, https://doi.org/10.3390/hydrology3040044, 2016.

Zhaoqing, Y., Kathryn, L. S., Danelle, H., Tarang, K., Ronald, T., and Roger, F.: Hydrodynamic and ecological assessment of nearshore restoration: A modeling study, Ecol. Modell., 221, 1043-1053, 2010. 